S. P. Karpova, M. Ye. Blazheyevskiy, O. O. Mozgova, M. M. Ivashura

National University of Pharmacy, Ukraine

\title{
The kinetic spectrophotometric method for the determination of azlocillin in solutions
}

Aim. To develop the method for the quantitative determination of azlocillin.

Materials and methods. The study object was Securopen ${ }^{\circledR}$ - a powder of azlocillin (Azl) sodium in vials for preparation of the solution for injections (Azlocillin, $1.0 \mathrm{~g}$ ). Peroxomonosulfate acid as triple potassium salt $2 \mathrm{KHSO}_{5} \cdot \mathrm{KHSO}_{4} \cdot \mathrm{K}_{2} \mathrm{SO}_{4}$ $\left(\mathrm{Oxone}^{\circledR}\right)$ of "extra pure" qualification was used as an oxidant.

Results and discussion. The kinetics of the conjugated reactions of S-oxidation and perhydrolysis of Azlocillin (Azl) with potassium peroxomonosulfate in the alkaline medium has been studied by the increase of the forming product light absorbance at $275 \mathrm{~nm}$. The conditions have been optimized, and the procedure of the quantitative analysis of Azl by the kinetic spectrophotometric method has been developed using potassium peroxomonosulfate as a reagent. $\mathrm{RSD}=2.02 \%$.

Conclusions. The results of the drug analysis obtained by the developed and standard methods are in good agreement with each other; $\delta=+0.49 \%$.

Key words: oxidation; azlocillin; validation; potassium peroxomonosulphate; spectrophotometry

С. П. Карпова, М. Є. Блажеєвський, О. О. Мозгова, М. М. Івашура

Національний фармацевтичний університет, Україна

Кінетико-спектрофотометричний метод визначення азлоциліну у розчинах

Мета. Метою даної роботи була розробка методики кількісного визначення азлоциліну.

Матеріали та методи. Об'єктом дослідження був Securopen ${ }^{\circledR}$ - порошок натрію азлоциліну у фрлаконах для приготування розчину для ін'єкцій (Азлоцилін 1,0 г). Як окисник використовували пероксомоносульфатну кислоту у вигляді потрійної калієвої солі $2 \mathrm{KHSO}_{5} \cdot \mathrm{KHSO}_{4} \cdot \mathrm{K}_{2} \mathrm{SO}_{4}$ кваліфікації "extra pure" (Oxone ${ }^{\circledR}$ ).

Результати та їх обговорення. Вивчена кінетика спряжених реакцій S-окиснення та пергідролізу азлоциліну з калію пероксомоносульфатом у лужному середовищі за світлопоглинанням утворюваного продукту при 275 нм. Оптимізовані умови та розроблена методика кількісного визначення азлоциліну кінетичним методом 3 використанням калію пероксомоносульфату. RSD = 2,02 \%.

Висновки. Результати аналізу препарату, одержані за новоопрацьованою та чинною методиками, добре узгоджуються між собою; $\delta=+0,49 \%$.

Ключові слова: окиснення; азлоцилін; валідація; калію пероксомоносульфат; спектрофротометрія

С. П. Карпова, Н. Е. Блажеевский, Е. А. Мозговая, М. Н. Ивашура

Национальный фармацевтический университет, Украина

Кинетико-спектрофотометрический метод определения азлоциллина в растворах

Цель. Целью данной работы была разработка методики количественного определения азлоциллина.

Материалы и методы. Объектом исследования был Securopen ${ }^{\circledR}$ - порошок натрия азлоциллина во флаконах для приготовления раствора для инъекций (Азлоциллин 1,0 г). Как окислитель использовали пероксомоносульфатную кислоту в виде тройной калиевой соли $2 \mathrm{KHSO}_{5} \cdot \mathrm{KHSO}_{4} \cdot \mathrm{K}_{2} \mathrm{SO}_{4}$ квалификации "extra pure" $\left(\mathrm{Oxone}^{\circledR}\right)$.

Результаты и их обсуждение. Изучена кинетика сопряженных реакций S-оксидирования и пергидролиза азлоциллина с пероксомоносульфатом калия в щелочной среде по светопоглощению образующегося продукта при 275 нм. Оптимизированы условия и разработана методика количественного определения азлоциллина кинетическим методом с использованием пероксомоносульфата калия. RSD $=2,02$ \%.

Выводы. Результаты анализа препарата, полученные с помощью разработанной и стандартной методик, хорошо согласуются между собой; $\delta=+0,49 \%$.

Ключевые слова: окисление; азлоциллин; валидация; пероксомоносульфат калия; спектрофоотометрия

Introduction. Azlocillin (Azl) is an acylampicillin antibiotic with the extended spectrum of activity and greater in vitro potency than carboxypenicillins. The activity of Azl and mezlocillin, new semisynthetic ureidopenicillins, was studied and compared to that of other known $\beta$-lactam antibiotics [1].

Different methods, such as biological, chemical and physicochemical are recommended for its quantitative determination. Biological methods are based on the direct antibiotic biological action on a test-microorganism sensitive to the given antibiotic. Disadvantages of the biological methods are the long-lasting procedure and the dependence of precision of the results on the external factors [2].

The extensive literature survey proposes various methods for the quantitative determination of penicillin 


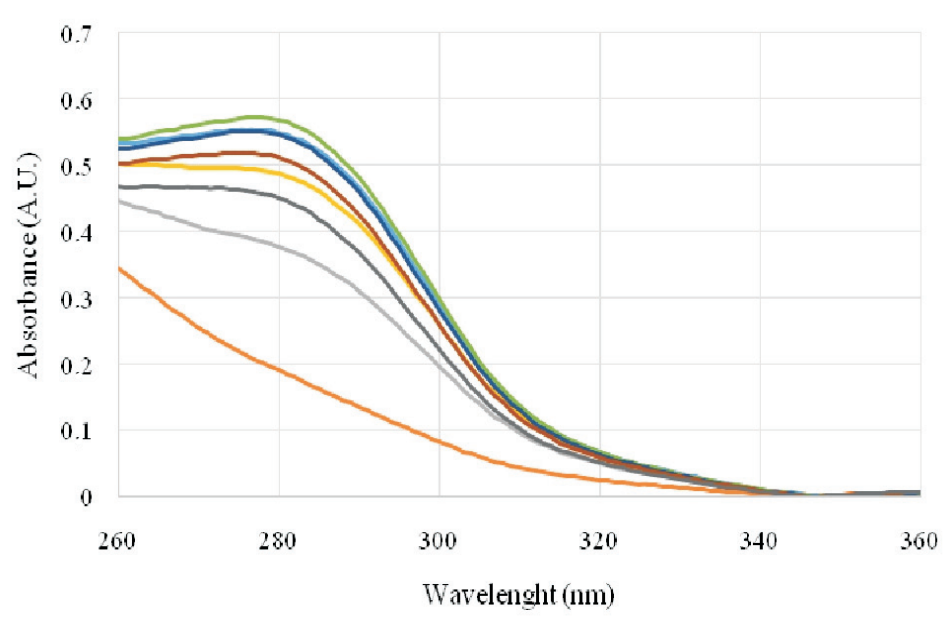

Fig. 1. UV absorption spectra of the system of $2 \cdot 10^{-4} \mathrm{~mol} / \mathrm{I} \mathrm{Azl}$ with $2 \cdot 10-3 \mathrm{~mol} / \mathrm{l}$ potassium caroate in $0.01 \mathrm{~mol} / \mathrm{L}$ of $\mathrm{NaOH}$ as a function of time (min): 1-3; 2-7; 3-11; 4-15; 5-19; 6-23; 7-27; 8-31

family preparations, such as HPLC, spectrophotometry, extraction photometry, iodometry, different variants of voltammetry, electrokinetic capillary chromatography and densitometry, kinetic analysis [3-11].

The aim of this study was to develop the method for the quantitative determination of azlocillin.

Materials and methods. All materials were of analytical reagent grade, and the solutions were prepared with double-distilled water.

The Azl sodium salt substance (CAS Number 37091-65-9) was used in the experiment. Azl sodium is the sodium salt form of Azl, a semi-synthetic agent, the extended spectrum acylampicillin with the antibacterial activity. Azl binds to penicillin-binding proteins located inside the bacterial cell wall, thereby inhibiting the cross-linkage of peptidoglycans, which are critical components of the bacterial cell wall. This prevents the synthesis of the proper bacterial cell wall, and results in weakening the bacterial cell wall and eventually leading to cell lysis. Its chemical structure is $(2 S, 5 R, 6 R)-3,3$-dimethyl-7-oxo-6- $\{[(2 R)-2-$ $\{[(2$-oxoimidazolidinyl)carbonyl $]$ amino $\}$-2-phenylacetyl]amino -4-thia-1-azabicyclo[3.2.0]heptane-2-carboxylate $\left(\mathrm{C}_{20} \mathrm{H}_{22} \mathrm{~N}_{5} \mathrm{NaO}_{6} \mathrm{~S}\right)[12]$.

Securopen $^{\circledR}$ - a powder of Azl sodium in vials for preparation of the solution for injections (Azlocillin, $1.0 \mathrm{~g}$ ), manufacturer Bayer, Switzerland, was studied in the present work.

The procedure for preparing the Azl sodium standard solution was as follows. $500 \mathrm{mg}$ of the Azl sodium salt substance was transferred to a $100 \mathrm{ml}$ volumetric flask, dissolved in $50 \mathrm{ml}$ of double distilled water, and the solution was diluted to the volume with double distilled water.

Potassium peroxomonosulfate was used as an oxidant in the view of a triple potassium salt $\left(2 \mathrm{KHSO}_{5}\right.$. $\mathrm{KHSO}_{4} \cdot \mathrm{K}_{2} \mathrm{SO}_{4}$ ) of the "extra pure" grade. Its commercial name is Oxone ${ }^{\circledR}$ with the content of active Oxygen of $4.5 \%$. It is available, has good solubility and stability in water. It was proposed for the cefadroxil kinetic spectrophotometric determination as an analytical reagent. The standard electrode potential for redox semi-reaction $\mathrm{HSO}_{5}{ }^{-}+$ $2 \mathrm{H}^{+}+2 \mathrm{e}^{-} \rightarrow \mathrm{HSO}_{4}^{-}+\mathrm{H}_{2} \mathrm{O}$ is $1.8 \mathrm{~V}$ [13-15].
The procedure for preparing the potassium peroxomonosulfate standard solution was as follows. $0.615 \mathrm{mg}$ of Oxon was transferred in a $100 \mathrm{~mL}$ volumetric flask and diluted to the volume with double distilled water at $20^{\circ} \mathrm{C}$. The solution of potassium caroate was standardized iodometrically.

Processing of the results was carried out by the "tangent method" (the differential version). The rate was estimated by the slope of the linear section of the kinetic curve A - time $\left(\operatorname{tg} \alpha_{a z l}, \min ^{-1}\right)$.

The method on the initial rates (tangent method) was used to collect kinetic data (usually at $275 \mathrm{~nm}$ ) following by appearance of the product of the perhydrolysis reaction of Azl. The solution of sodium hydroxide was thermostated in the cell compartment, and then the mixtures of solutions of Azl with the solutions of potassium peroxomonosulfate (the incubation time of $1 \mathrm{~min}$ ) were added to the cell. The resulting solution was mixed thoroughly and put into a spectrophotometer. The precision of the rate determination was usually $\pm 2-5 \%$.

Aliquots of $0.50-10.00 \mathrm{~mol} \mathrm{~L}^{-1}$ of the Azl test solutions studied were pipetted into a $50 \mathrm{~mL}$ volumetric flask containing $5 \mathrm{~mL}$ of $2 \cdot 10^{-2} \mathrm{~mol} \mathrm{~L}^{-1} \mathrm{KHSO}_{5}$ solution and mixed well. $5 \mathrm{~mL}$ of $0.06 \mathrm{~mol} \mathrm{~L}^{-1} \mathrm{NaOH}$ solution was added to the flask, diluted to the volume and mixed well. The stopwatch was switched on after addition of the alkaline solution. The increase in absorbance of the solution obtained at $275 \mathrm{~nm}$ was recorded as a function of time for $10 \mathrm{~min}$ against the reagent blank. It showed the dependence of the Azl alkaline solution absorption against time at $275 \mathrm{~nm}$. They have linear dependence for the first 10-15 min. The initial rate of the reaction at different concentrations was obtained from the slope of the tangent to absorbance time curves. The calibration graph was constructed by plotting the tangent of the initial rate of the reaction versus the concentration of $\mathrm{Azl}\left(\mathrm{C}, \mu \mathrm{g} \mathrm{mL} L^{-1}\right)$.

Results and discussion. The electronic spectra of the interaction product of Azl with reagents depending on time are shown in Fig. 1.

The results of the experiment showed that the order of mixing had its impact on the kinetics and the yield of 


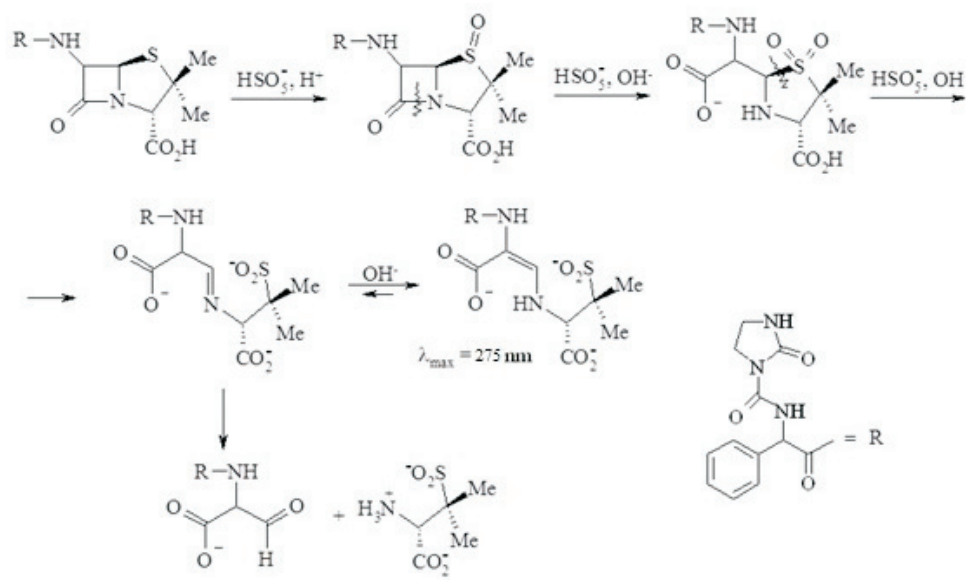

Fig. 2. The scheme of peroxo acid oxidation and perhydrolysis conjugated reactions of Azl

Table 1

Determination of Azl by the kinetic method using $\mathrm{KHSO}_{5}$ as an oxidizing agent

\begin{tabular}{|c|c|c|c|c|}
\hline Taken, $\mathrm{g}$ & $\begin{array}{c}\text { Determined by the } \\
\text { kinetic method, } \\
\bar{X} \pm \Delta \bar{X}\end{array}$ & RSD (\%) & $\delta=\frac{x-a}{a} \cdot 100 \%$ & $\begin{array}{c}\text { Recovery of the kinetic } \\
\text { method (\%) }\end{array}$ \\
\hline 1.346 & $1.36 \pm 0.029$ & 2.92 & +2.03 & 101.04 \\
\hline 2.827 & $2.84 \pm 0.041$ & 1.39 & +0.46 & 100.46 \\
\hline 5.498 & $5.55 \pm 0.052$ & 0.72 & +0.95 & 100.95 \\
\hline
\end{tabular}

Notes: * Average of seven determinations $(P=0.95)$.

the reaction. The highest rate of the product accumulation was observed only after prior mixing of the sample of Azl under study with potassium peroxomonosulfate, and therefore, with the alkaline solution. The maximum activity of potassium caroate in the reaction was achieved in the concentration of $2 \cdot 10^{-3} \mathrm{~mol} \mathrm{~L}^{-1}$.

The theoretical scheme of transformation of the reaction product is given in Fig. 2.

The calibration plot for kinetic determination of Azl in the optimal conditions given in Fig. 3 shows that the tga linear concentration dependence was observed within the Azl content in the solution - 1-50 $\mu \mathrm{g} \mathrm{mL}^{-1}$. This was a precondition for the possibility of using the kinetic method in the analysis.

The results obtained by the recommended procedure were for seven replicate titrations of mixtures containing three species in various concentrations. It is seen that Azl can be determined successively with good accuracy and reproducibility (Tab. 1).

The procedure of Azlocillin assay in vials was as follows. Azl sodium (ca $500 \mathrm{mg}$ ) was weighed accurately, dissolved in water and diluted to $100 \mathrm{ml}$. The content of the mixture was mixed well. $3.0 \mathrm{~mL}$ of the solution obtained was transferred in a $50 \mathrm{~mL}$ volumetric flask, further the calibration graph was constructed. The resulting solution was measured every minute photometrically in a quartz cuvette at $275 \mathrm{~nm}$ against distilled water (compensation solution) for the first $15 \mathrm{~min}$, and the absorbance kinetic curves against time were constructed. The slope of the linear section of the kinetic curve, $\operatorname{tg} \alpha$, was determined.
The results of the Azl quantitative determination are given in Tab. 2. The method proposed has good accuracy, $\mathrm{RSD}=2.02 \%$.

The content of $\mathrm{C}_{20} \mathrm{H}_{22} \mathrm{~N}_{5} \mathrm{NaO}_{6} \mathrm{~S}$, g, in one vial $\left(X_{A z l}\right)$ was calculated using the equation:

$$
X_{A z l}=\frac{a_{s t} \cdot \operatorname{tg} \alpha \cdot \bar{a}}{a \cdot \operatorname{tg} \alpha_{s t}},
$$

where: $a_{s t}$ - is the sample weight of the working standard of Azl, g; $\operatorname{tg} \alpha_{s t}$ - is the slope ratio of the kinetic curve in the experiment with the working standard of Azl, $\min ^{-1} ; a-$ is the sample weight of the Azl powder studied, $\mathrm{g} ; \bar{a}-$ is the average weight of the vial, g;

Table 2

The results of of the Azlocillin quantitative determination in Securopen ${ }^{\otimes}$ dosage form using potassium peroxomonosulfate $(\mathrm{P}=0.95, \mathrm{n}=7)$

\begin{tabular}{|c|c|c|c|}
\hline \multirow{2}{*}{$\begin{array}{c}\text { Nominal } \\
\text { Azl mass, g }\end{array}$} & \multicolumn{2}{|c|}{ Actual } & \multirow{2}{*}{$\begin{array}{c}\text { Metrological } \\
\text { characteristics }\end{array}$} \\
\cline { 2 - 3 } & $\mathrm{g}$ & $\%$ & \\
\hline \multicolumn{3}{|c|}{ SECUROPEN ${ }^{\circ}$ Bayer (Germany) } \\
\hline & 1.0018 & 100.08 & $\bar{x}=1.0072(100.62 \%)$ \\
& 1.0129 & 101.19 & $S= \pm 0.01138$ \\
$1.001^{*}$ & 0.9956 & 99.46 & $S_{\bar{x}}= \pm 0.0043$ \\
& 1.0258 & 102.48 & $\Delta \bar{x}= \pm 0.01054$ \\
& 1.0105 & 100.95 & RSD $=1.13 \%$ \\
& 1.0113 & 101.03 & $\varepsilon= \pm 1.05 \%$ \\
& 0.9928 & 99.18 & $\delta=+0.62 \%$ \\
\hline
\end{tabular}

Notes: *The content of Azl in the preparation was controlled by the independent method of iodometric titration [3]. 


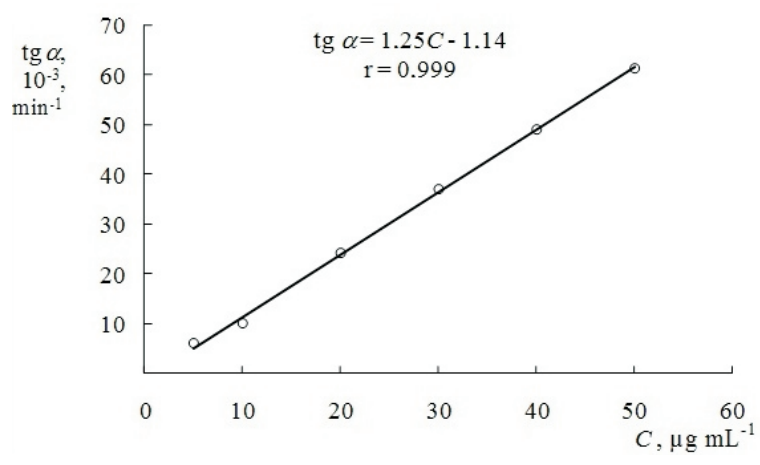

Fig. 3. The calibration plot for the kinetic determination of Azl using potassium peroxomonosulfate $\operatorname{tg} \alpha$-is the slope ratio of the kinetic curve in the experiment with the Azlocillin solution, $\mathrm{min}^{-1}$.

Conclusions and prospects of further research. The reaction kinetics of peroxyacidic oxidation and perhydrolysis of Azlocillin with potassium peroxomonosulfate in the alkaline medium has been studied. As an oxidizing agent the potassium triple salt of peroxymonosulfuric acid, $2 \mathrm{KHSO}_{5} \cdot \mathrm{KHSO}_{4} \cdot \mathrm{K}_{2} \mathrm{SO}_{4}$, syn. "Oxone", was used. The procedure has been developed, and the possibility of the quantitative determination of Azlocillin in Securopen ${ }^{\circledR}$ preparation based on the results of the kinetic spectrophotometric method with potassium peroxomonosulfate as a reagent has been shown. $\mathrm{RSD}=2.02 \%, \delta=+0.49 \%$.

Conflict of interests: authors have no conflict of interests to declare.

\section{REFERENCES}

1. Алексеев, В. Г. Тест-определение пенициллинов в лекарственных формах с использованием солей меди (II) / В. Г. Алексеев, С. В. Лапшин // Вопр. биол., мед. и фармац. химии. - 2007. - № 1. - С. 27-30.

2. Блажеєвський, М. Є. Полярографічне визначення пеніцилінів з використанням пероксикислотного окиснення / М. Є. Блажеєвський // Укр. хим. журн. - 2005. - Т. 71, № 10. - С. 90-93.

3. U.S. Pharmacopoeia 30-NF25, National Formulary 25, Pharmacopoeial Convention : Rockville. - 2008. - 2137 p.

4. Karpova, S. P. Development and validation of uv spectrophotometric area under curve method quantitative estimation of piperacillin / S. P. Karpova, M. Y. Blazheyevskiy, O. O. Mozgova // Int. J. Pharm. Sci. Res . - 2018. - Vol. 9, № 8. - P. 3556-3560. https://doi. org/10.13040/ijpsr.0975-8232.9(8).3556-60

5. Evaggelopoulou, E. Development and validation of an HPLC method for the determination of six penicillin and three amphenicol antibiotics in gilthead seabream (Sparus Aurata) tissue according to the European Union Decision 2002/657/EC / E. Evaggelopoulou, V. Samanidou // Food Chem. - 2013. - Vol. 136, № 3-4. - P. 1322-1329. https://doi.org/10.1016/j.foodchem.2012.09.044

6. Quantitative determination of azlocillin by iodometric method using potassium peroxomonosulfate / S. P. Karpova, M. Ye. Blazheyevskiy, Y. Yu. Serdiukova, O. O. Mozgova // Asian J. of Pharmac. - 2018. - Vol. 12, № 2. - P. 508-511. https://doi.org/10.22377/ajp. v12i02.2383

7. Liu, K. Assay detection for azlocillin sodium and sulbactam sodium for injection by HPLC / K. Liu, D. Sun, Y. Zhao // Chin. J. Pharm. Anal. - 2008. - Vol. 28, №9. - P. 1568-1570.

8. Khare, B. Spectrophotometric determination of antibiotic drug penicillin in pharmaceutical samples using 2,6 dichlorophenol indophenol, N-bromocaprolactam and N-chlorosuccinimide / B. Khare, K. Khare // Int. J. Rec. Res. Phys. Chem. Sci. - 2017. - Vol. 4. - P. 1-7.

9. Singh, D. Spectrophotometric determination of penicillins in pure and pharmaceutical formulations using Folin-Ciocalteu reagent / D. Singh, G. Maheshwari // Drug Test Anal. - 2010. - Vol. 2. - P. 503-506. https://doi.org/10.1002/dta.157

10. Sallach, J. Development and comparison of four methods for the extraction of antibiotics from a vegetative matrix / J. Sallach, D. Snow, L. Hodges // Envir. Toxicol. Chem. - 2016. - Vol. 35. - P. 889-897. https://doi.org/10.1002/etc.3214

11. Svorc, L. Voltammetric determination of penicillin V in pharmaceutical formulations and human urine using a boron-doped diamond electrode / L. Svorc, J. Sochr // Bioelectrochem. - 2012. - Vol. 88. - P. 36-41. https://doi.org/10.1016/j.bioelechem.2012.04.004

12. Dubenska, L. Voltammetric methods for the determination of pharmaceuticals / L. Dubenska, M. Blazhejevskyj, S. Plotycya // J. Meth. Obj. Chem. Anal. - 2017. - Vol. 12. - P. 61-75.

13. Hubicka, U. Simultaneous identification and quantitative determination of selected aminoglycoside antibiotics by thin-layer chromatography and densitometry/ U. Hubicka, J. Krzek, H. Woltynska // J. AOAC Int. - 2009. - Vol. 92. - P. 1068-1075.

14. Blazheyevskiy, M. Ye. Voltammetric determination of magnesium monoperoxyphthalate in pure substance and disinfectant "Dismozon pur" / M. Ye. Blazheyevskiy, O. O. Mozgova // Manag. Econom. Qual. Assurance. Pharm. - 2015. - Vol. 4. - P. 4-11.

15. Fluorescence sensing of peracetic acid by oxidative cleavage of phenylselenyl ether of 4-hydroxynaphthalimide / J. H. Baek, M. G. Choi, D. B. Kim, N. Ye. Kim // Tetrahed. Lett. - 2018. - Vol. 59, № 13. - P. 1254-1257. https://doi.org/10.1016/j.tetlet.2018.02.048

\section{REFERENCES}

1. Alekseev, V. G., Lapshin, S. V. (2007). Voprosy biologicheskoi, meditcinskoi i farmatcevticheskoi khimii, 1, 27-30.

2. Blazheievskyi, M. Ye. (2005). Ukrainskyi khimichnyi zhurnal, 71 (10), 90-93.

3. U.S. Pharmacopoeia 30-NF25, National Formulary 25. (2008). Pharmacopoeial Convention : Rockville, 2137.

4. Karpova, S. P., Blazheyevskiy, M. Y., Mozgova, O. O. (2018). Development and validation of uv spectrophotometric area under curve method quantitative estimation of piperacillin. International Journal of Pharmaceutical Sciences and Research, 9 (8), $3556-3560$.

5. Evaggelopoulou, E. N., \& Samanidou, V. F. (2013). Development and validation of an HPLC method for the determination of six penicillin and three amphenicol antibiotics in gilthead seabream (Sparus Aurata) tissue according to the European Union Decision 2002/657/ EC. Food Chemistry, 136 (3-4), 1322-1329. https://doi.org/10.1016/j.foodchem.2012.09.044

6. Karpova, S. P., Blazheyevskiy, M. Ye., Serdiukova, Y. Yu., Mozgova, O. O. (2018). Quantitative determination of azlocillin by iodometric method using potassium peroxomonosulfate. Asian Journal of Pharmaceutics, 12 (2), 508-511. https://doi.org/10.22377/ajp. v12i02.2383 
7. Liu, K., Sun, D., Zhao, Y. (2008). Assay detection for azlocillin sodium and sulbactam sodium for injection by HPLC. Chin. J. Pharm. Anal, 28 (9), 1568-1570.

8. Khare, B., Khare, K. (2017). Spectrophotometric determination of antibiotic drug penicillin in pharmaceutical samples using 2,6 dichlorophenol indophenol, N-bromocaprolactam and N-chlorosuccinimide. Int. J. Rec. Res. Phys. Chem. Sci, 4, 1-7.

9. Singh, D. K., \& Maheshwari, G. (2010). Spectrophotometric determination of penicillins in pure and pharmaceutical formulations using Folin-Ciocalteu reagent. Drug Testing and Analysis, 2 (10), 503-506. https://doi.org/10.1002/dta.157

10. Sallach, J. B., Snow, D., Hodges, L., Li, X., \& Bartelt-Hunt, S. (2015). Development and comparison of four methods for the extraction of antibiotics from a vegetative matrix. Environmental Toxicology and Chemistry, 35 (4), 889-897. https://doi.org/10.1002/etc.3214

11. Švorc, L., Sochr, J., Rievaj, M., Tomčík, P., \& Bustin, D. (2012). Voltammetric determination of penicillin V in pharmaceutical formulations and human urine using a boron-doped diamond electrode. Bioelectrochemistry, 88, 36-41. https://doi.org/10.1016/j.bioelechem.2012.04.004

12. Dubenska, L., Blazhejevskyj, M., Plotycya, S. (2017). Voltammetric methods for the determination of pharmaceuticals. J. Meth. Obj. Chem. Anal, 12, 61-75.

13. Hubicka, U., Krzek, J., Woltynska, H. (2009). Simultaneous identification and quantitative determination of selected aminoglycoside antibiotics by thin-layer chromatography and densitometry. J. AOAC Int, 92, 1068-1075.

14. Blazheyevskiy, M. Ye., Mozgova, O. O. (2015). Voltammetric determination of magnesium monoperoxyphthalate in pure substance and disinfectant "Dismozon pur". Manag. Econom. Qual. Assurance. Pharm, 4, 4-11.

15. Baek, J. H., Choi, M. G., Kim, D. B., Kim, N. Y., Kang, E., Ahn, S., \& Chang, S.-K. (2018). Fluorescence sensing of peracetic acid by oxidative cleavage of phenylselenyl ether of 4-hydroxynaphthalimide. Tetrahedron Letters, 59 (13), 1254-1257. https://doi. org/10.1016/j.tetlet.2018.02.048

Informations about authors:

Karpova S. P, Candidate of Pharmacy (Ph. D), associate professor of the Physical and Colloid Chemistry Department, National University of Pharmacy, Ukraine. E-mail: za9594506@gmail.com

Blazheyevskiy M. Ye., Doctor of Chemistry (Dr. habil), professor of the Physical and Colloid Chemistry Department, National University of Pharmacy, Ukraine. E-mail: blazejowski@ukr.net. ORCID: https://orcid.org/0000-0002-8032-347X

Mozgova O. O., Candidate of Pharmacy (Ph. D), teaching assistant of the Physical and Colloid Chemistry Department, National University of Pharmacy, Ukraine. E-mail: elena.mozgovaya25@gmail.com

Ivashura M. M., Candidate of Agricultural Sciences (Ph. D), teaching assistant of the Physical and Colloid Chemistry Department, National University of Pharmacy,

Ukraine. E-mail: ivashurakari@gmail.com

Відомості про авторів:

Карпова С. П., канд. фармац. наук, доцент кафедри фізичної та колоїдної хімії, Національний фармацевтичний університет, Україна. E-mail: za9594506@gmail.com

Блажеєвський М. Є., д-р хім. наук, професор кафедри фізичної та колоїдної хімії, Національний фармацевтичний університет, Україна. E-mail: blazejowski@ukr.net. ORCID: https://orcid.org/0000-0002-8032-347X

Мозгова О. О., канд. фармац. наук, асистент кафедри фізичної та колоїдної хімії, Національний фармацевтичний університет, Україна.

E-mail: elena.mozgovaya25@gmail.com. ORCID: http://orcid.org/0000-0003-0875-7035

Івашура М. М., канд. сільськогосп. наук, доцент кафедри фізичної та колоїдної хімії, Національний фармацевтичний університет, Україна.

E-mail: ivashurakari@gmail.com

Сведения об авторах:

Карпова С. П., канд. фармац. наук, доцент кафедры физической и коллоидной химии, Национальный фармацевтический университет, Украина.

E-mail: za9594506@gmail.com

Блажеевский Н. Е., д-р хим. наук, профессор кафедры физической и коллоидной химии, Национальный фармацевтический университет, Украина. E-mail: blazejowski@ukr.net. ORCID: https://orcid.org/0000-0002-8032-347X

Мозговая Е. А., канд. фармац. наук, асистент кафедры физической и коллоидной химии, Национальный фармацевтический университет, Украина. E-mail: elena.mozgovaya25@gmail.com. ORCID: http://orcid.org/0000-0003-0875-7035

Ивашура М. Н., канд. сельскохоз. наук, доцент, доцент кафедры физической и коллоидной химии, Национальный фармацевтический университет,

Харьков, Украина. E-mail: ivashurakari@gmail.com 